\title{
THE CLASSIFICATION OF COAGULASE-NEGATIVE MICROCOCCACEAE FROM HUMAN AND ANIMAL SOURCES
}

\author{
R. G. Mitchell*, V. G. Alder $\dagger$ and KIrSten Rosendal $\ddagger$ \\ * Department of Pathology, Churchill Hospital, Oxford, † Department of Pathology, United \\ Bristol Hospitals, Bristol, England, and $\ddagger$ Statens Seruminstitut, DK 2300 Copenhagen S., \\ Denmark
}

Coagulase-Negative Micrococcaceae isolated from the skin and fur of farm and zoo animals are in general much less active against a range of lipid substrates than are coagulasenegative strains from various human sources (Alder et al., 1973). This could be attributed either to biochemical differences resulting from adaptation of similar strains to different habitats, or to type differences between the strains acquired by the two groups. To investigate this problem, strains were classified by the system of biotyping devised by Baird-Parker (1963).

\section{MATERIALS AND METHODS}

The sources of strains and the methods of sampling are described by Alder $e$ t al. (1973). Representatives of each colonial type of catalase-positive, Gram-positive coccus obtained in primary culture were enumerated separately. Strains were again tested for coagulase production by the slide test for bound coagulase (Cadness-Graves et al., 1943) and in doubtful cases by the tube test of Gillespie (1943). They were classified by the methods described by Baird-Parker (1963), with the few minor modifications given below.

The glucose oxidation-fermentation (O-F) test used to classify strains as staphylococci or micrococci was carried out in Subcommittee (1965) medium distributed in 150-mm $\times 13-\mathrm{mm}$ tubes which were two-thirds filled with medium. The agar concentration was increased slightly to $0.3 \%$, as this appeared to ensure a more certain and even inoculation of those strains that were very adherent to the wire loop. Tubes were heavily stab-inoculated to the bottom from overnight cultures on nutrient agar or blood agar, and incubated at $37^{\circ} \mathrm{C}$ for 7 days without a paraffin seal. Organisms that produced acid at the surface of the agar column only, or that failed to produce acid, were classified as micrococci, while those that produced acid throughout the column were classified as staphylococci.

The novobiocin resistance of strains was determined by the disk-agar plate method, with $5-\mu \mathrm{g}$ novobiocin disks (Mast). Resistance was indicated by an inhibition zone less than $17 \mathrm{~mm}$ in diameter (Churcher, 1968; Corse and Williams, 1968). Novobiocin-sensitive strains were provisionally regarded as staphylococci, and resistant strains as micrococci (Mitchell and Baird-Parker, 1967). If there was disagreement between the results of the glucose O-F and novobiocin tests, the glucose O-F test was repeated, if necessary several times, after subculturing the organism on nutrient agar containing $1 \%$ glucose. The eventual classification was decided on the result of the glucose O-F test.

Acid production from lactose, mannitol and L-arabinose was tested in Subcommittee (1965) basal medium, incorporating each carbohydrate at $1 \%(w / v)$ final concentration. Short columns of media were stab-inoculated and incubated at $37^{\circ} \mathrm{C}$ for 7 days.

For the phosphatase reaction, phenolphthalein diphosphate (Oxoid) was incorporated at $0.01 \%(\mathrm{w} / \mathrm{v})$ final concentration in nutrient agar. A maximum of five strains were inoculated in the form of short surface streaks on each 9-cm plate, which was incubated at $30^{\circ} \mathrm{C}$ for 3 days.

Acetoin production was tested in Baird-Parker's (1963) medium, dispensed in 5-ml amounts and incubated at $30^{\circ} \mathrm{C}$ for 14 days.

Received 23 Mar. 1973; accepted 10 May 1973.

J. MED. MICROBIOL.-VOL. 7 (1974) 


\section{RESULTS}

A total of 677 strains was classified as shown in the table. Some strains gave equivocal results in the glucose O-F test, and the classification of 22 strains was ultimately revised, approximately equal numbers being transferred from each genus to the other. A group of 17 novobiocin-resistant strains isolated from bacon failed to produce acid from glucose at $37^{\circ} \mathrm{C}$ but attacked glucose oxidatively at $30^{\circ} \mathrm{C}$ and was allocated to Micrococcus subgroup 5.

TABLB

Classification of Micrococcaceae isolated from farm and zoo animals and from human sources

\begin{tabular}{|c|c|c|c|c|c|c|c|}
\hline \multirow{3}{*}{$\begin{array}{c}\text { Classification } \\
\text { (Baird-Parker, 1963) }\end{array}$} & \multicolumn{7}{|c|}{ Number of strains from } \\
\hline & \multicolumn{4}{|c|}{ human sourcest } & \multirow{2}{*}{$\begin{array}{c}\text { zoo } \\
\text { animals }\end{array}$} & \multirow{2}{*}{$\begin{array}{c}\text { farm } \\
\text { animals }\end{array}$} & \multirow{2}{*}{ bacon } \\
\hline & $\mathbf{a}$ & $\mathbf{b}$ & c & d & & & \\
\hline $\begin{array}{l}\text { STAPHYLOCOCCI } \\
\text { SII } \\
\text { SIII } \\
\text { SIV } \\
\text { SV } \\
\text { SVI }\end{array}$ & $\begin{array}{c}52(1) \\
1 \\
1 \\
7 \\
20(1)\end{array}$ & $\begin{array}{r}102 \\
0 \\
5 \\
27 \\
12\end{array}$ & $\begin{array}{r}26 \\
0 \\
9 \\
9 \\
7\end{array}$ & $\begin{array}{l}42(1) \\
0 \\
3(1) \\
6(1) \\
9(1)\end{array}$ & $\begin{array}{l}1 \\
2 \\
0 \\
3 \\
2\end{array}$ & $\begin{array}{l}0 \\
5 \\
0 \\
1(1) \\
3\end{array}$ & $\begin{array}{l}\mathbf{0} \\
\mathbf{0} \\
\mathbf{0} \\
\mathbf{0} \\
\mathbf{0}\end{array}$ \\
\hline Total staphylococci & 81 & 146 & 51 & 60 & 8 & 9 & 0 \\
\hline $\begin{array}{c}\text { MicRococcI } \\
\text { M2 } \\
\text { M3 } \\
\text { M4 } \\
\text { M5 } \\
\text { M6 } \\
\text { M7 }\end{array}$ & $\begin{array}{l}3(1) \\
8(4) \\
0 \\
0 \\
0 \\
0\end{array}$ & $\begin{array}{r}0 \\
52 \\
0 \\
0 \\
0 \\
0\end{array}$ & $\begin{array}{l}2 \\
0 \\
0 \\
0 \\
0 \\
0\end{array}$ & $\begin{array}{l}4(1) \\
2(1) \\
0 \\
0 \\
5 \\
0\end{array}$ & $\begin{array}{c}0 \\
3 \\
3 \\
117(2) \\
22 \\
5(1)\end{array}$ & $\begin{array}{l}12(3) \\
5 \\
0 \\
36(1) \\
20 \\
0\end{array}$ & $\begin{array}{l}4(1) \\
1 \\
0 \\
17 \\
1 \\
0\end{array}$ \\
\hline Total micrococci & 11 & 52 & 2 & 11 & 150 & 73 & 23 \\
\hline Total strains & 92 & 198 & 53 & 71 & 158 & 82 & 23 \\
\hline
\end{tabular}

* Numbers in parentheses denote strains classified only after revision of the glucose O-F test.

$\dagger \mathrm{a}=$ Carrier sites, sputum and wound swabs, Bristol; $b=$ urine, Bristol; $c=$ acne lesions, Bristol (Alder, Mitchell and Walshe, unpublished observations); $d=$ sputum, urine, blood culture, Denmark.

Twenty-six strains that oxidised glucose and were classified as micrococci were sensitive to novobiocin. They included 19 of the 23 Micrococcus subgroup-2 strains, two Micrococcus subgroup-3 strains and five Micrococcus subgroup-5 strains.

All strains classified as staphylococci by the glucose O-F test were novobiocin sensitive.

\section{Discussion}

The strains obtained from human sources showed a predominance of staphylococci in all groups studied, with the notable exception of a collection of Micrococcus subgroup-3 strains causing urinary-tract infections in otherwise healthy young women (Mitchell, 1968). BairdParker (1962) found that $84.5 \%$ of Micrococcaceae isolated from normal human skin were staphylococci. In a study of acne lesions (Alder, Mitchell and Walshe, unpublished observations), 84 of 87 strains obtained from 51 patients were staphylococci. Noble (1969) investi- 
gated skin carriage of the Micrococcaceae, and found that staphylococci and micrococci were present in roughly equal numbers, although the commonest biotype was Staphylococcus subgroup II/III (these subgroups were combined). Corse and Williams (1968) found that staphylococci predominated in pathological lesions and at the carrier sites of hospital and non-hospital personnel, but micrococci predominated among airborne strains obtained outside hospital. Holt (1969) found that infections of ventriculo-venous shunts causing bacteriaemia were due almost invariably to Staphylococcus subgroup-II strains. His survey of organisms isolated from the skin of babies and adults both inside and outside hospital showed a predominance of staphylococci over micrococci in all case-groups, Staphylococcus subgroup-II being invariably the commonest biotype.

In the present study, 223 out of 246 strains isolated from the skin and hair of farm and zoo animals were micrococci, belonging mainly to Micrococcus subgroups 5 and 6 . No previous studies of the distribution of the Micrococcaceae among various animal populations appear to have been carried out.

The taxonomic position of the genera Staphylococcus and Micrococcus remains a matter of dispute. Evans, Bradford and Niven (1955) based the division on the mode of glucose metabolism. Staphylococci produced acid fermentatively under anaerobic conditions, whereas micrococci either produced acid oxidatively under aerobic conditions or failed to attack glucose. This definition was accepted by Breed in Bergey's Manual (1957), and was used as the basis of Baird-Parker's (1963) classification in a survey of strains isolated from bacon, human and pig skin, and dust. It was endorsed by the Subcommittee on Taxonomy of Staphylococci and Micrococci $(1965,1971)$, which proposed a standard glucose O-F test carried out as a one-tube test in a simple defined medium with a paraffin seal. In the present study, the test was done without a seal, on the assumption that weakly oxidising strains might sometimes be detected in an open but not in a sealed column. In practice, there was usually very little difficulty in interpreting the result. A few strains gave variable or equivocal reactions, but these are also encountered when a seal or a two-tube test is employed (V. T. Schuhardt, cited by Baird-Parker, 1965; Kocur and Mortensen, 1967; Noble, 1969). However, Chalmers (1972) considered that equivocal reactions could be eliminated by substituting a solid paraffin seal for liquid paraffin to prevent diffusion of air into the medium, as well as by reducing the concentration of bromocresol purple to $0.002 \%$.

The separation of strains achieved by the glucose O-F test is generally in agreement with the results of several other apparently unrelated tests, including DNA-base composition (Rosypal, Rosypalová and Hơ̌ejš, 1966), novobiocin resistance (Mitchell and Baird-Parker, 1967; Jeffries, 1968; Lacey and Boswell, 1968); susceptibility to lysostaphin (Schindler and Schuhardt, 1964), and arginase production (Mortensen and Kocur, 1967).

However, the validity of the glucose O-F test in the classification of the Micrococcaceae has been questioned. Mortensen (1970), investigating the final $p \mathrm{H}$ of broth cultures incubated anaerobically, found that a large series of strains produced a continuous range of $p \mathrm{H}$ values with no interval to suggest a separation of staphylococci from micrococci. Again, certain organisms that would be regarded as typical micrococci on their cultural and physiological properties and belong mainly to Baird-Parker's Micrococcus subgroups 1-4, are found to have a low guanine-cytosine ratio characteristic of staphylococci (Subcommittee, 1971). Evans and Kloos (1972) showed that micrococci of subgroups 1-4 would grow throughout the depth of a column of thioglycollate agar, and considered that these strains were staphylococci. If this view is upheld, the broad difference in the generic composition of the animal and human strains in the present study becomes even more pronounced, because most of the animal strains were undoubted micrococci that belonged to Micrococcus subgroups 5 and 6 , whereas most of the human " micrococci" were allocated to Micrococcus subgroup 3.

\section{SUMMARY}

Six hundred and seventy-seven strains of coagulase-negative Micrococcaceae isolated from human and animal sources were classified by Baird-Parker's (1963) system. The human strains showed a predominance of staphylococci in the main clinical categories, although strains causing primary urinary-tract infections in otherwise healthy women were nearly all 
allocated to Micrococcus subgroup 3. Organisms isolated from the fur and skin of farm and zoo animals were predominantly micrococci, 170 out of 263 strains being allocated to Micrococcus subgroup 5. The generic separation of staphylococci from micrococci is briefly discussed.

We wish to thank Professor W. A. Gillespie for his advice and encouragement, Dr K. R. Eriksen, Dr N. Mortensen, Dr O. Klaustrup and Dr J. Patterson for supplying cultures, and Mrs L. Monies and Mrs J. Lockyer for technical assistance.

\section{REFERENCES}

Alder, V. G., Gillespie, W. A., Mrtchell, R. G. ANd Rosendal, K. 1973. The lipolytic activity of Micrococcaceae from human and animal sources. J. med. Microbiol., 6, 147.

BAIRD-PARKER, A. C. 1962. The occurrence and enumeration, according to a new classification, of micrococci and staphylococci in bacon and on human and pig skin. J. appl. Bact., 25, 352.

BAIRD-PARKER, A. C. 1963. A classification of micrococci and staphylococci based on physiological and biochemical tests. J. gen. Microbiol., 30, 409.

BaIrD-PARKer, A. C. 1965. Staphylococci and their classification. Ann. N.Y. Acad. Sci., $128,4$.

BREED, R. S. 1957. In Bergey's Manual of determinative bacteriology, 7th ed., edited by R. S. Breed, E. G. D. Murray and N. R. Smith, Baltimore, p. 454.

Cadness-Graves, B., Williams, R. E. O., Harper, G. J. AND Miles, A. A. 1943. Slide test for coagulase-positive staphylococci. Lancet, 1, 736.

Chalmers, A. 1972. A modification of the oxidation/fermentation test for the classification of Micrococcaceae. Med. Lab. Technol., 29, 379.

Churcher, G. M. 1968. A screening test for the detection of methicillin-resistant staphylococci. J. Clin. Path., 21, 213.

CORSE, J. AND WILLIAMS, R. E. O. 1968. Antibiotic resistance of coagulase-negative staphylococci and micrococci. J. clin. Path., 21, 722.

Evans, J. B., Bradford, W. L. JR AND Niven, C. F. JR 1955. Comments concerning the taxonomy of the genera Micrococcus and Staphylococcus. Int. Bull. bact. Nomencl. Taxon., 5, 61.

Evans, J. B. AND KLoos, W. E. 1972. Use of shake cultures in a semi-solid thioglycolate medium for differentiating staphylococci from micrococci. Appl. Microbiol., 23, 326.

GILlESPIE, E. H. 1943. The routine use of the coagulase test for staphylococci. Mon. Bull. Emerg. publ. Hlth Lab. Serv., 2, 19.

Holt, R. 1969. The classification of staphylococci from colonised ventriculo-atrial shunts. J. clin. Path., 22, 475.

JEFFRIES, L. 1968. Sensitivity to novobiocin and lysozyme in the classification of Micrococcaceae. J. appl. Bact., 31, 436.

KoCUR, M. AND MORTENSEN, N. 1967. Comparison of methods for estimation of anaerobic production of acid from glucose and mannitol in staphylococci and micrococci. Acta path. microbiol. scand., 71, 141.

LACEY, R. W. AND BosWELL, P. A. 1968. Resistance to paromomycin, bacitracin and novobiocin in the Micrococcaceae. J. appl. Bact., 31, 302.

Mrtchell, R. G. 1968. Classification of Staphylococcus albus strains isolated from the urinary tract. J. clin. Path., $21,93$.

Mrtchell, R. G. AND BAIRD-PARKer, A. C. 1967. Novobiocin-resistance and the classification of staphylococci and micrococci. J. appl. Bact., 30, 251.

MORTENSEN, N. 1970. Separation of staphylococci from micrococci on the basis of anaerobic production of acid from glucose. Publ. Fac. Sci. Univ. J. E. Purkinye, Brno, K47, 157.

MORTENSEN, N. AND KocUR, M. 1967. Correlation of DNA base composition and acid formation from glucose of staphylococci and micrococci. Acta path. microbiol. scand., 69, 445. 
Noble, W. C. 1969. Skin carriage of the Micrococcaceae. J. clin. Path., 22, 249.

Rosypal, S., RosypalovÁ, A. AND HoŘEjš, J. 1966. The classification of micrococci and staphylococci based on their DNA base composition and Adansonian analysis. J. gen. Microbiol., 44, 281.

SCHINDLER, C. A. AND SchuHARDT, V. T. 1964. Lysostaphin, a new bacteriolytic agent for the staphylococcus. Proc. natn. Acad. Sci., USA, 51, 414.

Subcommittee on TAXonomy OF Staphylococci AND Micrococci. 1965. Minutes of first meeting. Int. Bull. bact. Nomencl. Taxon., 15, 107.

SUbCOMMTTEE ON TAXONOMY OF STAPHYLOCOCCI AND MiCROCOCCI. 1971. Minutes of meeting, 2 and 3 April, 1968. Int. J. syst. Bact., 21161. 